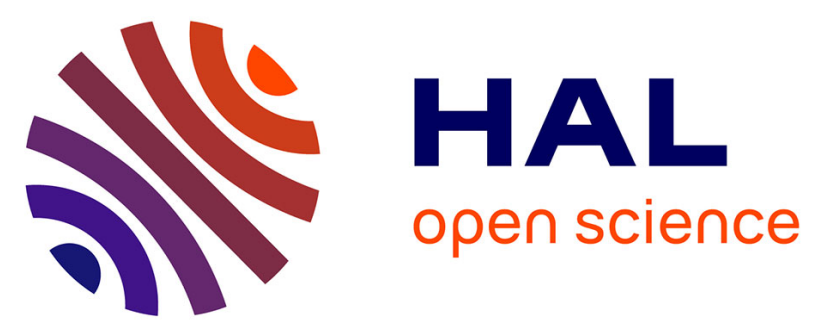

\title{
Metatranscriptomic outlook on green and brown food webs in acid mine drainage
}

Frédéric Plewniak, Simona Crognale, Odile Bruneel, Odile Sismeiro, Jean-Yves Coppée, Simona Rossetti, Philippe Bertin

\section{To cite this version:}

Frédéric Plewniak, Simona Crognale, Odile Bruneel, Odile Sismeiro, Jean-Yves Coppée, et al.. Metatranscriptomic outlook on green and brown food webs in acid mine drainage. Environmental Microbiology Reports, 2021, 10.1111/1758-2229.12958 . pasteur-03228510

\section{HAL Id: pasteur-03228510}

\section{https://hal-pasteur.archives-ouvertes.fr/pasteur-03228510}

Submitted on 8 Feb 2022

HAL is a multi-disciplinary open access archive for the deposit and dissemination of scientific research documents, whether they are published or not. The documents may come from teaching and research institutions in France or abroad, or from public or private research centers.
L'archive ouverte pluridisciplinaire HAL, est destinée au dépôt et à la diffusion de documents scientifiques de niveau recherche, publiés ou non, émanant des établissements d'enseignement et de recherche français ou étrangers, des laboratoires publics ou privés.

\section{다)(1) $(5$}

Distributed under a Creative Commons Attribution - NonCommercial| 4.0 International 


\section{Metatranscriptomic outlook on green and brown food webs in acid mine drainage}

\author{
Frédéric Plewniak, (1) ${ }^{1 *}$ Simona Crognale, ${ }^{2}$ \\ Odile Bruneel, ${ }^{3}$ Odile Sismeiro, ${ }^{4,5}$ Jean-Yves Coppée, ${ }^{4,6}$ \\ Simona Rossetti ${ }^{2}$ and Philippe Bertin ${ }^{1}$ \\ ${ }^{1}$ Génétique Moléculaire, Génomique et Microbiologie, \\ UMR7156, CNRS - University of Strasbourg, \\ Strasbourg, France. \\ ${ }^{2}$ Istituto di Ricerca Sulle Acque, Consiglio Nazionale \\ Delle Ricerche, Rome, Italy. \\ ${ }^{3}$ HydroSciences Montpellier, University of Montpellier - \\ CNRS - IRD, Montpellier, France. \\ ${ }^{4}$ Institut Pasteur, Transcriptome and Epigenome \\ Platform, Biomics Pole, Paris, France. \\ ${ }^{5}$ Unité de Biologie des Bactéries Pathogènes à Gram \\ Positif, Institut Pasteur, Paris, France. \\ ${ }^{6}$ Biologie des ARN des Pathogènes Fongiques, Institut \\ Pasteur, Paris, France.
}

Acid mine drainages (AMDs), metal-rich acidic effluents generated by mining activities, are colonized by prokaryotic and eukaryotic microorganisms widely distributed among different phyla. We compared metatranscriptomic data from two sampling stations in the Carnoulès AMD and from a third station in the nearby Amous River, focussing on processes involved in primary production and litter decomposition. A synergistic relationship between the green and brown food webs was favoured in the AMD sediments by the low carbon content and the availability of mineral nutrients: primary production of organic matter would benefit C-limited decomposers whose activity of organic matter mineralization would in turn profit primary producers. This balance could be locally disturbed by heterogeneous factors such as an input of plant debris from the riparian vegetation, strongly boosting the growth of Tremellales which would then outcompete primary producers. In the unpolluted Amous River on the contrary, the competition for limited mineral nutrients was dominated by the green food web, fish and bacterivorous protists having a positive effect on phytoplankton. These results suggest that in addition to direct effects of low $\mathrm{pH}$ and metal contamination, trophic conditions like carbon or mineral nutrient limitations also have a strong impact on assembly and activities of AMDs' microbial communities.

\section{Introduction}

Acid mine drainages (AMDs) are generated by the exposition to water and oxygen of sulfide minerals excavated by coal or metal mining activities (Johnson, 2003). Despite their hostility and toxicity (Levings et al., 2004; Dsa et al., 2008), those metal-rich acidic effluents are colonized by prokaryotic and eukaryotic microbial communities which have been extensively reviewed (Hallberg, 2010; Méndez-García et al., 2015; Andres and Bertin, 2016; Chen et al., 2016). Although the prokaryotic richness is usually lower in AMDs, observed species are widely distributed among different phyla: Proteobacteria, Actinobacteria, Firmicutes, Acidobacteria, Bacteroidetes, Nitrospirae, sulfur and/or iron-oxidizing archaea and methanogens (Edwards, 2000; Golyshina et al., 2000; Baker and Banfield, 2003; Dopson et al., 2004; Bertin et al., 2011; Volant et al., 2012; Mesa et al., 2017). The main eukaryotic microorganisms reported in those environments are green algae (i.e. Chlamydomonas, Chlorella, Coccomyxa), protozoa (i.e. Euglenozoa, Amoebozoa, Stramenopiles, Alveolates, Rhizaria) and Fungi (Baker et al., 2004, 2009; Hao et al., 2010; AmaralZettler, 2012; Zirnstein et al., 2012; Aguilera, 2013; Aliaga Goltsman et al., 2015; Halter et al., 2015; Koechler et al., 2016; Volant et al., 2016; Mesa et al., 2017).

Despite a strong focus on metal and sulfur transformations, those studies nonetheless provide some insights on trophic interactions and the role that may be played by the respective microorganisms in the carbon biogeochemical cycle. Primary producers include chemolithoautotrophs oxidizing $\mathrm{Fe}$ (II) or sulfur and, in areas exposed to sunlight, photoautotrophs such as Cyanobacteria, Euglena and algae (Baker and Banfield, 2003; Rowe et al., 2007; Bertin et al., 2011; Halter et al., 2015; Koechler et al., 2016; 
Volant et al., 2016; Mesa et al., 2017). Heterotrophs feeding on organic compounds may help keep organic levels low by removing lysates and exudates that can be toxic to primary producers (Clark and Norris, 1996; BacelarNicolau and Johnson, 1999; Baker et al., 2004; Xiao et al., 2013). The AMD prokaryotic communities involved in key biogeochemical transformations may also be affected by the presence of protists able to graze on acidophilic bacteria (McGinness and Johnson, 1992; Johnson and Rang, 1993; Baker et al., 2004; Volant et al., 2016). Although AMDs are oligotrophic environments (Dodds et al., 1998), the abundance of fungi suggests an active decomposition of organic matter (Amils et al., 2007; Das et al., 2009; Volant et al., 2016). The identification of genes coding for a cellulase and an $\alpha$-amylase in the CARN6 bin of Carnoulès metagenome further suggests that the corresponding strain was able to metabolize complex carbohydrates (Bertin et al., 2011). Those complex polysaccharides may originate from components of cell wall and biofilm but also from potential extraneous sources of organic matter like dead leaves, plant debris, decaying wood or bat guano (Bruneel et al., 2011; Johnson, 2012; Volant et al., 2016). The importance of leaf litter as a source of energy in woodland streams is well known indeed (Fisher and Likens, 1973; Iversen et al., 1982; Siefert and Mutz, 2001) and, in the absence of shredding invertebrates, fungi are expected to play a major role as decomposers of complex organic matter (Das et al., 2009).

In this study, we present a comparative analysis of metatranscriptomic data from two different sampling stations (Conf and Gal) of the Reigous creek, in the Carnoulès AMD and from a third station (Ams) situated downstream in the nearby Amous River (Fig. 1). Our analyses focus on processes involved in primary production and litter decomposition, aiming at the identification of broad trophic patterns and food web relative activities at each station.

\section{Results and discussion}

The first factorial plane of the correspondence analysis (Fig. 2) represented $89.7 \%$ of the total variation of the data, indicating that the variation across samples of the relative abundance of orders could be accurately represented on the first two axes. The first axis, accounting for $69.7 \%$ of the total variation separated Gal1, Gal2 and Ams1 from all other samples (all Conf samples, Gal3, Ams2 and Ams3) according to the abundance of Tremellales reads. Samples from the contaminated Gal station and from the non-contaminated Amous River (Ams) were found on both sides of the origin, suggesting some heterogeneity of the corresponding factor within the sampling stations independently of their level of contamination. This heterogeneity of Tremellales read

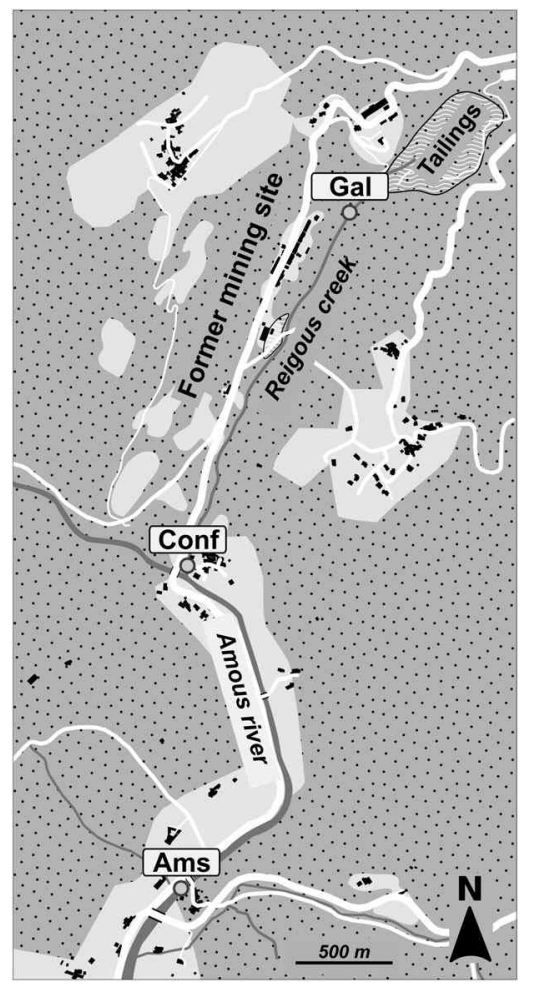

Fig 1. Map of the Carnoulès acid mine drainage area. Tailings that were accumulated during the exploitation of the now abandoned $\mathrm{Pb} / \mathrm{Zn}$ mine of Carnoulès are drained by the Reigous creek which parallels the former mining site before joining the Amous River in the Fabrègues hamlet. Medium grey-dotted areas represent woodlands and dense vegetation. Light grey areas represent open land. The location of the sampling stations in this study - Gal, Conf and Ams are represented by a labelled grey disk. The Gal station, situated on the Reigous closest to the tailings stockpiles, is surrounded by woodland. The Conf station is located in open land in the small hamlet of Fabrègues just before the confluence with the Amous River. The Ams station is $1200 \mathrm{~m}$ downstream the confluence on the Amous River.

abundance across samples from the same station may reflect heterogeneous input of allochtonous organic matter, dead leaves and plant debris, from the riparian vegetation (Fisher and Likens, 1973; Wallace et al., 1999; Volant et al., 2016). In this study indeed, Tremellales were essentially represented by the Cryptococcus genus which includes cellulolytic and ligninolytic primary decomposers dwelling on dead leaves, decaying wood and in freshwater (Nakase et al., 1996; Fell et al., 2011; Prakash et al., 2018). Metatranscript assembly followed by coding sequence (CDS) prediction and annotation allowed the identification of laccase, cellulase, chitinase and $\alpha$-amylase enzymes belonging to the Cryptococcus genus. In addition, the taxonomic classification by Kaiju of reads mapping to the predicted glycoside hydrolase CDSs (Fig. 3) suggested that Tremellales were the main decomposers of lignin, cellulose and other glucans. The degradation of recalcitrant polysaccharides by 


\section{Correspondence analysis}

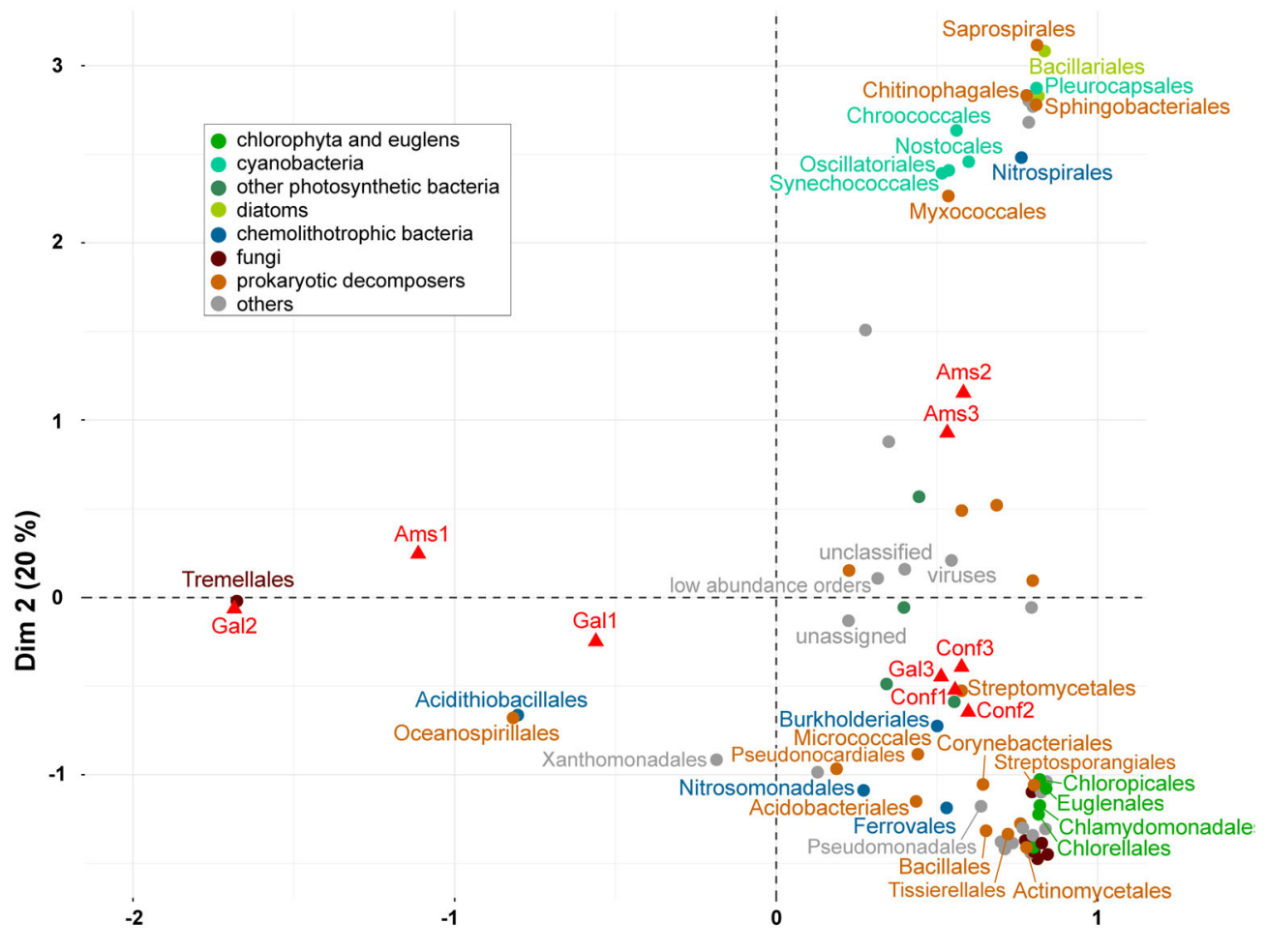

$\operatorname{Dim} 1(69.7 \%)$

Fig 2. Correspondence analysis of taxonomic classification data by Kaiju (Menzel et al., 2016) at the order level, using only orders representing at least $0.1 \%$ of all reads in a sample. The first two dimensions account for $89.7 \%$ of the total variance in the data. Gal1, Gal2 and Ams 1 are related to the saprophytic fungi Tremellales (brown food web) along the first axis. Conf samples, as well as Gal3, are associated with a combination of phyla representative of both green and brown food webs: decomposers (Bacillales, Actinobacteria, etc.) and primary producers such as Chlorophyta and chemolithotrophic bacteria (Burkholderiales, Nitrosomonadales, etc.). The green food web is strongly represented in Ams2 and Ams3 samples by photosynthetic orders of the Cyanobacteria phylum or diatoms.

Tremellales would increase the availability of decaying organic matter as a source of carbon and energy for secondary decomposers and other heterotrophs. Those food chains based on detritus decomposition are denoted by the term 'brown food web', in opposition to the 'green food web' driven by primary production (Allison, 2006; Butler et al., 2008; Zou et al., 2016). Thus, in areas receiving plant debris, the microbial communities would not be limited by the amount of organic carbon but by mineral nutrient availability instead, a condition where active cycling of mineral nutrients within the brown food web would favour decomposers and have a limiting effect on primary producers (Zou et al., 2016). As a matter of fact, Fig. 3 shows that the expression of genes related to photosynthesis and carbon fixation is lower in samples where the expression of cellulose and lignin degradation genes by Tremellales is higher compared with other samples of the same station (Gal1 and Gal2 vs. Gal3, Ams1 vs. Ams2 and Ams3), suggesting some competition between brown and green food webs in those samples.
The second axis, representing $20.0 \%$ of the total variation of data distinguished the non-contaminated samples taken in the Amous River from the contaminated samples of the Reigous creek, reflecting the influence of AMD conditions on Conf and Gal microbial communities in comparison with Ams station. Previous studies have shown that low-pH conditions constitute the main factor affecting diversity of microbial communities in AMDs, although temperature, ionic composition, total organic carbon, and dissolved oxygen may also have a significant influence (Volant et al., 2014; Méndez-García et al., 2015). In this study, the C:N:P stoichiometry of the Reigous sediments (Table 1) further suggested an absence of deficiency of $\mathrm{N}$ and $\mathrm{P}$ (Hecky et al., 1993). It is thus expected that primary producers were not in competition with decomposers for mineral nutrients, except in Gal1 and Gal2 samples where an input of allochtonous organic matter might have strongly boosted the activity of Tremellales as suggested above. In Gal3 and Conf samples where no expression was observed for lignin degradation genes, suggesting they did not undergo any input 


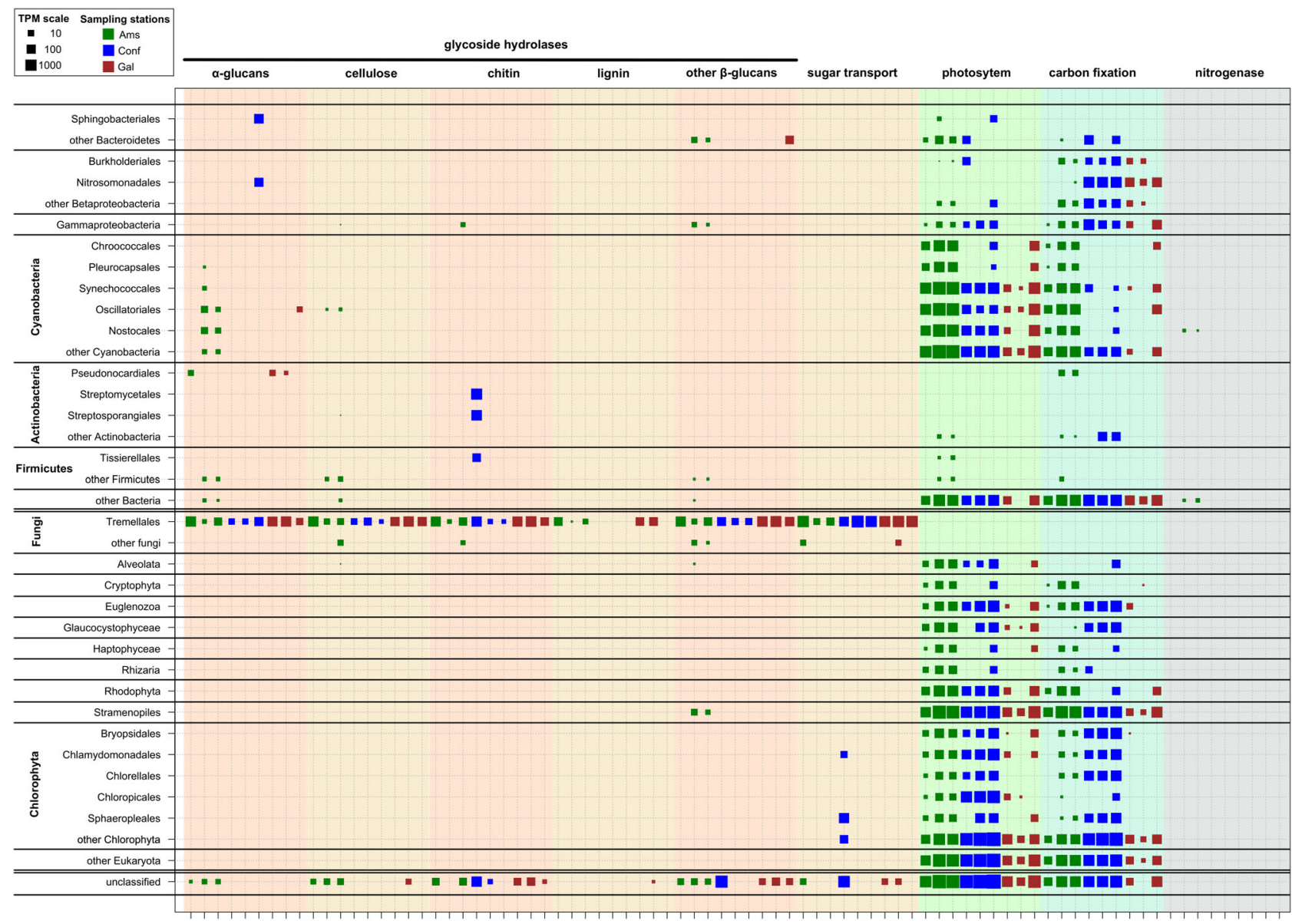

Fig 3. Expression values in transcripts by million (TPM) for functional groups of genes by order in each sample created with the rioja $0.8-5$ package in R 3.6.3 (R Core Team, 2020). The colour of squares indicate the sampling station (green = Ams, blue $=$ Conf, brown $=$ Gal) and their size is proportional to the $\log _{10}$ of the corresponding expression value in TPM. The complete figure is available as Supporting Information Fig. S1. After merging using the BBMerge program from the BBTools suite, reads were assembled with rnaSpades 3.13.0 (Bushmanova et al., 2019) separately in one batch per sample. CDSs longer than 240 bases were predicted and translated using TransDecoder 5.5.0 (https://github.com/Trans Decoder/TransDecoder) and the 128506 predicted proteins were annotated with Interproscan 5.35-74.0 (Jones et al., 2014) and dbCAN2 version 2.0.1 (Zhang et al., 2018) with the CaZy database (Lombard et al., 2014) as of the 31th of July 2019. The CaZy GH numbers and Interpro entries used to define the functional groups are given in Supporting Information Table S3. Transcript quantification was performed with Salmon 1.1.0 (Patro et al., 2017) in quasi mapping mode using quality-filtered read pairs from each replicate of each sample separately. Reads mapping CDSs were kept for each functional group and sample prior to their taxonomic classification by orders with Kaiju. TPM values of each functional group in every sample were computed for each order as: $\operatorname{TPM}_{i, j, k}=\operatorname{TPM}_{i, j} \times f_{i, j, k}$, where $\operatorname{TPM}_{i, j, k}$ is the TPM value for group $i$, sample $j$ and order $k, \mathrm{TPM}_{i, j}$ is the TPM value computed by Salmon for group $i$ and sample $j$, and $f_{i, j, k}$ is the proportion of reads from sample $j$ mapping to CDSs in group $i$ that were classified as order $k$ by Kaiju.

of plant debris, primary production (photosystems and carbon fixation) is more active indeed than in Gal1 and Gal2 (Fig. 3). The bioavailability of metals and the very low organic carbon content of sediments would favour chemolithotrophs able to use metals for energy production like Burkholderiales, Nitrosomonadales and other Betaproteobacteria and Gammaproteobacteria. Photosynthetic organisms like Chlorophyta, Stramenopiles, Euglenales and to a lesser extent Cyanobacteria and other photosynthetic bacteria were also active in the Reigous. The primary production of organic matter would benefit C-limited decomposers whose activity of organic matter mineralization would in turn profit primary producers in a synergistic relationship between the green and brown food webs (Daufresne and Loreau, 2001; Zou et al., 2016).

The Reigous AMD brown food web was represented not only by fungi but also by orders of the Bacteroidetes, Actinobacteria and Firmicutes phyla. Only the order of Tremellales though was consistently expressing all the genes coding for glucan degradation enzymes examined in this study. Bacterial orders of decomposers showed more specialization towards a few types of glucans only (Fig. 3). Sphingobacterales and Nitrosomonadales in Conf1, Pseudonocardiales in Gal1 and Gal2 were all expressing genes encoding $\alpha$-glucosidases. However, 


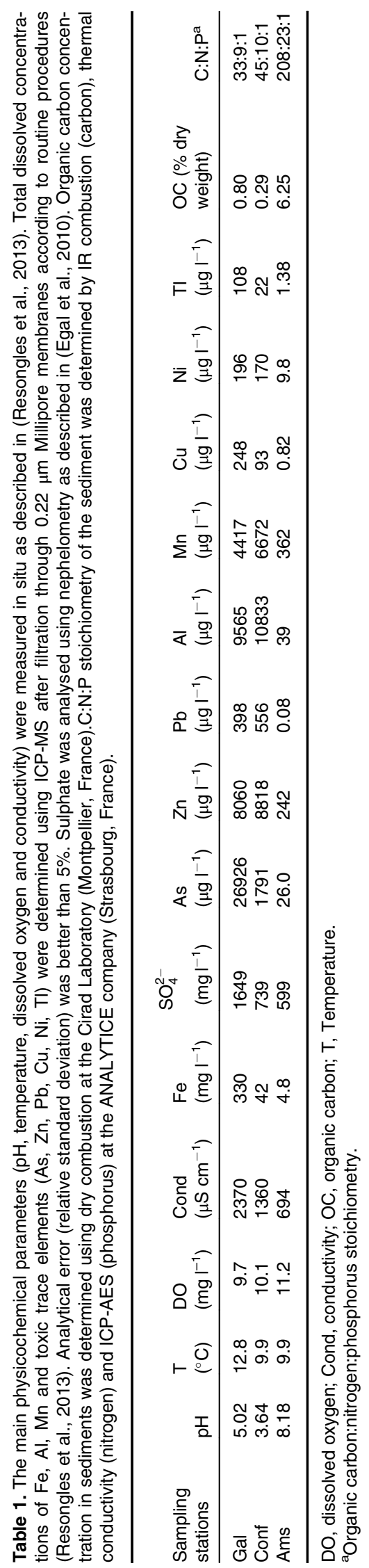


the expression of $\alpha$-glucosidase genes by Cyanobacteria might be related to the biosynthesis or degradation of their own storage polymer glycogen instead of decomposition (Shinde et al., 2020). In addition to Tremellales, chitinase genes were expressed in Conf1 by Streptomycetales, Streptosporangiales and Tissierellales. Since chitin is an essential compound of the fungal cell wall, this observation would suggest that Actinobacteria (Streptomycetales, Streptosporangiales) and Firmicutes were playing an active role as decomposers of dead fungal cells or as predators of fungi (Chet et al., 1971; Kumbhar and Watve, 2013; Lacombe-Harvey et al., 2018; Starke et al., 2020). It is probable as well that the chitin degradation by Tremellales at all stations may correspond to the recycling of dead fungal biomass or to the reorganization of their own cell wall during growth.

Expression of sugar-transport genes could be detected only for fungi except in Conf1 where it was observed also for Sphaeropleales, Chlamydomonadales and other Chlorophyta whose order could not be predicted, suggesting a mixotrophic lifestyle. Sphaeropleales, Chlamydomonadales and other green algae like Coccomyxa have been shown indeed to be capable of heterotrophic or mixotrophic growth with a better yield than autotrophy when a source of carbon is available (Laliberté and de la Noüe, 1993; Casal et al., 2010; Suzuki et al., 2018). Those Chlorophyta may thus have taken advantage of decomposers' activity in Conf1 to enhance their growth and as such would have participated in both green and brown food webs.

The impact of pollution from the Reigous AMD on the Amous River was considerably attenuated at the Ams station, $1.2 \mathrm{~km}$ downstream from confluence (Table 1). The C:N:P stoichiometry of the Amous River sediments was quite typical of a primary stream and suggested a moderate limitation of phytoplankton by $\mathrm{N}$ and $\mathrm{P}$ (Hecky et al., 1993). This limitation by mineral nutrients would imply a competition between the green and brown food webs with an outcome depending upon various factors that could not be addressed in this study, like predation rate or nutrient release (Zou et al., 2016). Expression of photosystem genes was very active in the Amous River samples for a wide range of microorganisms: Cyanobacteria, Stramenopiles, Rhizaria, Rhodophyta, Chlorophyta, Glaucocystophyceae, Haptophyceae, Euglenales (Fig. 3). Along with the larger proportion of photosystem-related CDSs assembled from Ams samples compared with Conf and Gal (Supporting Information Table S4), this would suggest dominance of the green food web in the Amous River.

Fish, like the common roach or the perch, are known to have a beneficial effect on primary producers, directly by providing mineral nutrients through their excretions and indirectly through predation on grazing microcrustaceans (Carpenter and Kitchell, 1993; Brett and Goldman, 1996; Attayde and Hansson, 2001; Danger et al., 2012; Zou et al., 2016). Conditions encountered in the Amous River allowed for the presence of fish (Casiot et al., 2009) and the green food web may thus benefit from their presence. This sharply contrasted with Gal1 and Gal2 where the brown food web outcompeted the green food web. Fish are absent from Gal station due to the low $\mathrm{pH}$, and the presence of metals like iron, manganese, aluminium and arsenic, zinc, lead, copper. In particular, aluminium concentrations in the Reigous AMD are largely superior to those shown to cause death of fish with a high probability (Witters, 1986; Gagen et al., 1993; Baldigo and Murdoch, 1997; Baldigo et al., 2020). Bacterivorous protozoa like Ciliophora, Amoebozoa, Choanoflagellida and Kinetoplastida - identified by Kaiju in larger proportions in Ams than in Conf and Gal (Supporting Information Fig. S2) - may also have a positive effect on phytoplankton growth by reducing the amount of mineral nutrients trapped in the brown food web (Caron et al., 1988; Ferrier and Rassoulzadegan, 1991; Saleem et al., 2016; Zou et al., 2016).

Although all photosynthetic phyla were represented in both the Amous River and Reigous AMD, the second dimension of the correspondence analysis clearly indicated that microbial photosynthetic activities were characterized by Cyanobacteria at Ams and Chlorophyta at Conf (Fig. 2). It is probable that this difference could not be strictly attributed to the higher arsenic contamination at Conf since cyanobacterial photosynthetic activity was observed in all Reigous samples. The C:N ratios of 9.0 at Ams and 4.5 at Conf indicated that phytoplankton might be moderately limited by nitrogen in the Amous River but not at Conf (Hecky et al., 1993). The expression of nitrogenase nifH gene by Nostocales and other bacteria observed at Ams (Fig. 3) further suggested that nitrogen fixation might have contributed to the relative success of Cyanobacteria in the Amous River by allowing them to use dinitrogen, a source of nitrogen that Chlorophyta are unable to tap.

We have performed here a metatranscriptomic analysis on sediments from the Carnoulès AMD and the nearby Amous River, focussing on processes related to primary production, litter decomposition and trophic interactions. Both green and brown food chains comprise several trophic levels from primary producers or decomposers up to top predators. Although nutrient cycling can occur actively within a food chain (Caron et al., 1988; Attayde and Hansson, 2001; Leroux and Loreau, 2010; Berdjeb et al., 2011), green and brown food webs are coupled by nutrient fluxes (Polis and Strong, 1996; Rooney et al., 2006; Boit et al., 2012; Cherif and Loreau, 2013; Mougi, 2020). The activity of one food web may generate 
cascading effects that can influence the activity and production of trophic levels in the other one (Carpenter et al., 1985; Carpenter and Kitchell, 1993; Leroux and Loreau, 2010; Zou et al., 2016). Bacterivorous protists for instance may reduce the amount of mineral nutrients trapped in the brown food web, making those nutrients more available to phytoplankton (Caron et al., 1988; Ferrier and Rassoulzadegan, 1991; Saleem et al., 2016; Zou et al., 2016). Thus, depending upon resource availability and community structure, the direct and indirect interactions between decomposers and primary producers will result in either synergy or competition (Caron et al., 1988; Daufresne and Loreau, 2001; Daufresne et al., 2008). Originally developed to describe macroecosystems, these notions have since been extended to microorganisms, which play a major role in detritus decomposition and primary production (Steffan and Dharampal, 2019). In this study, the C-limited Reigous AMD microbial community generally achieved a synergistic relationship between the green and brown food webs. Competition for mineral nutrients would occur though if the resource balance was disturbed by allochtonous input of organic matter, strongly favouring decomposers. In the uncontaminated Amous River, the translocation of organic matter by metazoa would extend the carbon cycle well beyond the microbial community in comparison with the Reigous AMD, with a different outcome to the competition for mineral nutrients in favour of the green food web. In this regard, microbial communities might be significantly affected by their surroundings. Extending the scope of the study beyond the mere sampling points would integrate microorganisms into a more complete network of interdependence within a metaecosystemic point of view. Interactions between microorganisms and macroorganisms play an important role in natural ecosystems and the disruption or disturbance of these interactions in anthropized contaminated environments may have dramatic effects on the structure and activity of microbial communities. We thus suggest that the interpretation of metatranscriptomic data should consider information about the surroundings of the studied ecosystem in order to gain a better insight of microbial communities' activity. In our time of global warming and biological diversity crisis, this may be of crucial importance for a better understanding and management of the effects that anthropic perturbations of the Earth microbiota may have, directly or not, on soil fertility and water quality.

\section{Acknowledgements}

This study was supported by the Agence Nationale de la Recherche (ANR) within the scope of the ANR-12-ADAP0013 project and benefited from the financial support of the
DMO/DMA project subsidized by the CNRS national programme EC2CO-MicrobiEn. We acknowledge Corinne Casiot for providing samples and their physicochemical characterization acquired during the framework of the POLLUMINE Observatory (OSU OREME, University of Montpellier). We thank the OSU OREME (SO POLLUMINE Observatory) for long term funding of physicochemical and microbiological monitoring since 2009.

\section{Conflict of interest}

The authors declare no conflict of interest.

\section{Data availability statement}

Metatranscriptomic raw data were made available in the SRA database under the bioproject number PRJEB38318. Replicate samples received the accession numbers ERS4560396 (Ams1), ERS4560397 (Ams2), ERS4560398 (Ams3), ERS4560399 (Conf1), ERS4560400 (Conf2), ERS4560401 (Conf3), ERS4560402 (Gal1), ERS4560403 (Gal2) and ERS4560404 (Gal3).

\section{References}

Aguilera, A. (2013) Eukaryotic organisms in extreme acidic environments, the Río Tinto case. Life (Basel) 3: 363-374.

Aliaga Goltsman, D.S., Comolli, L.R., Thomas, B.C., and Banfield, J.F. (2015) Community transcriptomics reveals unexpected high microbial diversity in acidophilic biofilm communities. ISME J 9: 1014-1023.

Allison, S.D. (2006) Brown ground: a soil carbon analogue for the green world hypothesis? Am Nat 167: 619-627.

Amaral-Zettler, L.A. (2012) Eukaryotic diversity at $\mathrm{pH}$ extremes. Front Microbiol 3: 441.

Amils, R., González-Toril, E., Fernández-Remolar, D., Gómez, F., Aguilera, Á., Rodríguez, N., et al. (2007) Extreme environments as Mars terrestrial analogs: the Rio Tinto case. Planet Space Sci 55: 370-381.

Andres, J., and Bertin, P.N. (2016) The microbial genomics of arsenic. FEMS Microbiol Rev 40: 299-322.

Attayde, J.L., and Hansson, L.-A. (2001) Fish-mediated nutrient recycling and the trophic cascade in lakes. Can J Fish Aquat Sci 58: 1924-1931.

Bacelar-Nicolau, P., and Johnson, D.B. (1999) Leaching of pyrite by acidophilic heterotrophic iron-oxidizing bacteria in pure and mixed cultures. Appl Environ Microbiol 65: 585-590.

Baker, B.J., and Banfield, J.F. (2003) Microbial communities in acid mine drainage. FEMS Microbiol Ecol 44: 139-152.

Baker, B.J., Lutz, M.A., Dawson, S.C., Bond, P.L., and Banfield, J.F. (2004) Metabolically active eukaryotic communities in extremely acidic mine drainage. Appl Environ Microbiol 70: 6264-6271.

Baker, B.J., Tyson, G.W., Goosherst, L., and Banfield, J.F. (2009) Insights into the diversity of eukaryotes in acid mine drainage biofilm communities. Appl Environ Microbiol 75: 2192-2199. 
Baldigo, B.P., George, S.D., Lawrence, G.B., and Paul, E.A. (2020) Declining aluminum toxicity and the role of exposure duration on brook trout mortality in acidified streams of the Adirondack Mountains, New York, USA. Environ Toxicol Chem 39: 623-636.

Baldigo, B.P., and Murdoch, P.S. (1997) Effect of stream acidification and inorganic aluminum on mortality of brook trout (Salvelinus fontinalis) in the Catskill Mountains, New York. Can J Fish Aquat Sci 54: 603-615.

Berdjeb, L., Pollet, T., Domaizon, I., and Jacquet, S. (2011) Effect of grazers and viruses on bacterial community structure and production in two contrasting trophic lakes. BMC Microbiol 11: 88.

Bertin, P.N., Heinrich-Salmeron, A., Pelletier, E., GoulhenChollet, F., Arsène-Ploetze, F., Gallien, S., et al. (2011) Metabolic diversity among main microorganisms inside an arsenic-rich ecosystem revealed by meta- and proteogenomics. ISME J 5: 1735-1747.

Boit, A., Martinez, N.D., Williams, R.J., and Gaedke, U. (2012) Mechanistic theory and modelling of complex foodweb dynamics in Lake Constance: mechanistic modelling of complex food web dynamics. Ecol Lett 15: 594-602.

Brett, M.T., and Goldman, C.R. (1996) A meta-analysis of the freshwater trophic cascade. Proc Natl Acad Sci 93: 7723-7726.

Bruneel, O., Volant, A., Gallien, S., Chaumande, B., Casiot, C., Carapito, C., et al. (2011) Characterization of the active bacterial community involved in natural attenuation processes in arsenic-rich creek sediments. Microb Ecol 61: 793-810.

Bushmanova, E., Antipov, D., Lapidus, A., and Prjibelski, A. D. (2019) rnaSPAdes: a de novo transcriptome assembler and its application to RNA-Seq data. GigaScience 8: giz100.

Butler, J.L., Gotelli, N.J., and Ellison, A.M. (2008) Linking the brown and green: nutrient transformation and fate in the Sarracenia microecosystem. Ecology 89: 898-904.

Caron, D.A., Goldman, J.C., and Dennett, M.R. (1988) Experimental demonstration of the roles of bacteria and bacterivorous protozoa in plankton nutrient cycles. Hydrobiologia 159: 27-40.

Carpenter, S.R., and Kitchell, J.F. (eds). (1993) The Trophic Cascade in Lakes, 1st ed: Cambridge, England: Cambridge University Press.

Carpenter, S.R., Kitchell, J.F., and Hodgson, J.R. (1985) Cascading trophic interactions and lake productivity. Bioscience 35: 634-639.

Casal, C., Cuaresma, M., Vega, J.M., and Vilchez, C. (2010) Enhanced productivity of a lutein-enriched novel acidophile microalga grown on urea. Mar Drugs 9: 29-42.

Casiot, C., Egal, M., Elbaz-Poulichet, F., Bruneel, O., Bancon-Montigny, C., Cordier, M.-A., et al. (2009) Hydrological and geochemical control of metals and arsenic in a Mediterranean river contaminated by acid mine drainage (the Amous River, France); preliminary assessment of impacts on fish (Leuciscus cephalus). Appl Geochem 24: 787-799.

Chen, L., Huang, L., Méndez-García, C., Kuang, J., Hua, Z., Liu, J., and Shu, W. (2016) Microbial communities, processes and functions in acid mine drainage ecosystems. Curr Opin Biotechnol 38: 150-158.
Cherif, M., and Loreau, M. (2013) Plant-herbivoredecomposer stoichiometric mismatches and nutrient cycling in ecosystems. Proc R Soc B 280: 20122453.

Chet, I., Fogel, S., and Mitchell, R. (1971) Chemical detection of microbial prey by bacterial predators. J Bacteriol 106: 863-867.

Clark, D.A., and Norris, P.R. (1996) Acidimicrobium ferrooxidans gen. nov., sp. nov.: mixed-culture ferrous iron oxidation with Sulfobacillus species. Microbiology 142: 785-790.

Danger, M., Allard, B., Arnous, M.B., Carrias, J.-F., Mériguet, J., Ten-Hage, L., and Lacroix, G. (2012) Effects of food-web structure on the quantity and the elemental quality of sedimenting material in shallow lakes. Hydrobiologia 679: 251-266.

Das, B.K., Roy, A., Koschorreck, M., Mandal, S.M., WendtPotthoff, K., and Bhattacharya, J. (2009) Occurrence and role of algae and fungi in acid mine drainage environment with special reference to metals and sulfate immobilization. Water Res 43: 883-894.

Daufresne, T., Lacroix, G., Benhaim, D., and Loreau, M. (2008) Coexistence of algae and bacteria: a test of the carbon hypothesis. Aquat Microb Ecol 53: 323-332.

Daufresne, T., and Loreau, M. (2001) Ecological stoichiometry, primary producer-decomposer interactions, and ecosystem persistence. Ecology 82: 3069-3082.

Dodds, W.K., Jones, J.R., and Welch, E.B. (1998) Suggested classification of stream trophic state: distributions of temperate stream types by chlorophyll, total nitrogen, and phosphorus. Water Res 32: 1455-1462.

Dopson, M., Baker-Austin, C., Hind, A., Bowman, J.P., and Bond, P.L. (2004) Characterization of Ferroplasma isolates and Ferroplasma acidarmanus sp. nov., extreme acidophiles from acid mine drainage and industrial bioleaching environments. App Environ Microbiol 70: 20792088.

Dsa, J.V., Johnson, K.S., Lopez, D., Kanuckel, C., and Tumlinson, J. (2008) Residual toxicity of acid mine drainage-contaminated sediment to stream macroinvertebrates: relative contribution of acidity vs. metals. Water Air Soil Pollut 194: 185-197.

Edwards, K.J. (2000) An archaeal iron-oxidizing extreme acidophile important in acid mine drainage. Science 287: 1796-1799.

Egal, M., Casiot, C., Morin, G., Elbaz-Poulichet, F., Cordier, M.-A., and Bruneel, O. (2010) An updated insight into the natural attenuation of as concentrations in Reigous Creek (southern France). Appl Geochem 25: 1949-1957.

Fell, J.W., Statzell-Tallman, A., Scorzetti, G., and Gutiérrez, M.H. (2011) Five new species of yeasts from fresh water and marine habitats in the Florida Everglades. Antonie Van Leeuwenhoek 99: 533-549.

Ferrier, C., and Rassoulzadegan, F. (1991) Densitydependent effects of protozoans on specific growth rates in pico- and nanoplanktonic assemblages. Limnol Oceanogr 36: 657-669.

Fisher, S.G., and Likens, G.E. (1973) Energy flow in bear brook, New Hampshire: an integrative approach to stream ecosystem metabolism. Ecol Monogr 43: 421-439. 
Gagen, C.J., Sharpe, W.E., and Carline, R.F. (1993) Mortality of brook trout, mottled sculpins, and slimy sculpins during acidic episodes. Trans Am Fish Soc 122: 616-628.

Golyshina, O.V., Pivovarova, T.A., Karavaiko, G.I., Kondratéva, T.F., Moore, E.R., Abraham, W.R., et al. (2000) Ferroplasma acidiphilum gen. nov., sp. nov., an acidophilic, autotrophic, ferrous-iron-oxidizing, cell-walllacking, mesophilic member of the Ferroplasmaceae fam. nov., comprising a distinct lineage of the Archaea. Int $J$ Syst Evol Microbiol 50: 997-1006.

Hallberg, K.B. (2010) New perspectives in acid mine drainage microbiology. Hydrometallurgy 104: 448-453.

Halter, D., Andres, J., Plewniak, F., Poulain, J., Da Silva, C., Arsène-Ploetze, F., and Bertin, P.N. (2015) Arsenic hypertolerance in the protist Euglena mutabilis is mediated by specific transporters and functional integrity maintenance mechanisms. Environ Microbiol 17: 1941-1949.

Hao, C., Wang, L., Gao, Y., Zhang, L., and Dong, H. (2010) Microbial diversity in acid mine drainage of Xiang Mountain sulfide mine, Anhui Province, China. Extremophiles 14: 465-474.

Hecky, R.E., Campbell, P., and Hendzel, L.L. (1993) The stoichiometry of carbon, nitrogen, and phosphorus in particulate matter of lakes and oceans. Limnol Oceanogr 38: 709-724.

Iversen, T.M., Thorup, J., and Skriver, J. (1982) Inputs and transformation of allochthonous particulate organic matter in a headwater stream. Ecography 5: 10-19.

Johnson, D.B. (2003) Chemical and microbiological characteristics of mineral spoils and drainage waters at abandoned coal and metal mines. Water Air Soil Pollut Focus 3: 47-66.

Johnson, D.B. (2012) Geomicrobiology of extremely acidic subsurface environments. FEMS Microbiol Ecol 81: 2-12.

Johnson, D.B., and Rang, L. (1993) Effects of acidophilic protozoa on populations of metal-mobilizing bacteria during the leaching of pyritic coal. J Gen Microbiol 139: 1417-1423.

Jones, P., Binns, D., Chang, H.-Y., Fraser, M., Li, W., McAnulla, C., et al. (2014) InterProScan 5: genome-scale protein function classification. Bioinformatics 30: 12361240.

Koechler, S., Bertin, P.N., Plewniak, F., Baltenweck, R., Casiot, C., Heipieper, H.J., et al. (2016) Arsenite response in Coccomyxa sp. Carn explored by transcriptomic and non-targeted metabolomic approaches. Environ Microbiol 18: $1289-1300$.

Kumbhar, C., and Watve, M. (2013) Why antibiotics: a comparative evaluation of different hypotheses for the natural role of antibiotics and an evolutionary synthesis. Nat Sci 05: $26-40$.

Lacombe-Harvey, M.-̇̀., Brzezinski, R., and Beaulieu, C. (2018) Chitinolytic functions in actinobacteria: ecology, enzymes, and evolution. Appl Microbiol Biotechnol 102: 7219-7230.

Laliberté, G., and de la Noüe, J. (1993) Auto-, hetero-, and mixotrophic growth of Chlamidomonas humicola (Chlorophyceae) on acetate. J Phycol 29: 612-620.

Leroux, S.J., and Loreau, M. (2010) Consumer-mediated recycling and cascading trophic interactions. Ecology 91 : 2162-2171.
Levings, C.D., Barry, K.L., Grout, J.A., Piercey, G.E., Marsden, A.D., Coombs, A.P., and Mossop, B. (2004) Effects of acid mine drainage on the estuarine food web, Britannia Beach, Howe Sound, British Columbia, Canada. Hydrobiologia 525: 185-202.

Lombard, V., Golaconda Ramulu, H., Drula, E., Coutinho, P. M., and Henrissat, B. (2014) The carbohydrate-active enzymes database (CAZy) in 2013. Nucleic Acids Res 42: D490-D495.

McGinness, S., and Johnson, D.B. (1992) Grazing of acidophilic bacteria by a flagellated protozoan. Microb Ecol 23: 75-86.

Méndez-García, C., Pelaez, A.I., Mesa, V., Sanchez, J., Golyshina, O.V., and Ferrer, M. (2015) Microbial diversity and metabolic networks in acid mine drainage habitats. Front Microbiol 6: 475.

Menzel, P., Ng, K.L., and Krogh, A. (2016) Fast and sensitive taxonomic classification for metagenomics with Kaiju. Nat Commun 7: 11257.

Mesa, V., Gallego, J.L.R., González-Gil, R., Lauga, B., Sánchez, J., Méndez-García, C., and Peláez, A.I. (2017) Bacterial, archaeal, and eukaryotic diversity across distinct microhabitats in an acid mine drainage. Front Microbiol 8: 1756.

Mougi, A. (2020) Coupling of green and brown food webs and ecosystem stability. Ecol Evol 10: 9192-9199.

Nakase, T., Suzuki, M., Hamamoto, M., Takashima, M., Hatano, T., and Fukui, S. (1996) A taxonomic study on cellulolytic yeasts and yeast-like microorganisms isolated in Japan. II. The genus Cryptococcus. J Gen Appl Microbiol 42: 7-15.

Patro, R., Duggal, G., Love, M.I., Irizarry, R.A., and Kingsford, C. (2017) Salmon provides fast and bias-aware quantification of transcript expression. Nat Methods 14: 417-419.

Polis, G.A., and Strong, D.R. (1996) Food web complexity and community dynamics. Am Nat 147: 813-846.

Prakash, A., Randhawa, H.S., Khan, Z.U., Ahmad, S., Hagen, F., Meis, J.F., and Chowdhary, A. (2018) Environmental distribution of Cryptococcus species and some other yeast-like fungi in India. Mycoses 61: 305-313.

R Core Team. (2020) R: A Language and Environment for Statistical Computing. Vienna, Austria: R Foundation for Statistical Computing.

Resongles, E., Casiot, C., Elbaz-Poulichet, F., Freydier, R., Bruneel, O., Piot, C., et al. (2013) Fate of $\mathrm{Sb}(\mathrm{v})$ and $\mathrm{Sb}$ (iii) species along a gradient of $\mathrm{pH}$ and oxygen concentration in the Carnoulès mine waters (Southern France). Environ Sci Process Impacts 15: 1536.

Rooney, N., McCann, K., Gellner, G., and Moore, J.C. (2006) Structural asymmetry and the stability of diverse food webs. Nature 442: 265-269.

Rowe, O.F., Sánchez-España, J., Hallberg, K.B., and Johnson, D.B. (2007) Microbial communities and geochemical dynamics in an extremely acidic, metal-rich stream at an abandoned sulfide mine (Huelva, Spain) underpinned by two functional primary production systems: microbial communities in an extremely acidic stream. Environ Microbiol 9: 1761-1771.

Saleem, M., Fetzer, I., Harms, H., and Chatzinotas, A. (2016) Trophic complexity in aqueous systems: bacterial 
species richness and protistan predation regulate dissolved organic carbon and dissolved total nitrogen removal. Proc $R$ Soc B 283: 20152724.

Shinde, S., Zhang, X., Singapuri, S.P., Kalra, I., Liu, X., Morgan-Kiss, R.M., and Wang, X. (2020) Glycogen metabolism supports photosynthesis start through the oxidative pentose phosphate pathway in cyanobacteria. Plant Physiol 182: 507-517.

Siefert, J., and Mutz, M. (2001) Processing of leaf litter in acid waters of the post-mining landscape in Lusatia, Germany. Ecol Eng 17: 297-306.

Starke, R., Morais, D., Větrovský, T., Mondéjar, R.L., Baldrian, P., and Brabcová, V. (2020) Feeding on fungi: genomic and proteomic analysis of the enzymatic machinery of bacteria decomposing fungal biomass. Environ Microbiol 22: 4604-4619.

Steffan, S.A., and Dharampal, P.S. (2019) Undead foodwebs: integrating microbes into the food-chain. Food Webs 18: e00111.

Suzuki, S., Yamaguchi, H., Nakajima, N., and Kawachi, M. (2018) Raphidocelis subcapitata (=Pseudokirchneriella subcapitata) provides an insight into genome evolution and environmental adaptations in the Sphaeropleales. Sci Rep 8: 8058.

Volant, A., Bruneel, O., Desoeuvre, A., Héry, M., Casiot, C., Bru, N., et al. (2014) Diversity and spatiotemporal dynamics of bacterial communities: physicochemical and other drivers along an acid mine drainage. FEMS Microbiol Ecol 90: 247-263.

Volant, A., Desoeuvre, A., Casiot, C., Lauga, B., Delpoux, S., Morin, G., et al. (2012) Archaeal diversity: temporal variation in the arsenic-rich creek sediments of Carnoulès Mine, France. Extremophiles 16: 645-657.

Volant, A., Héry, M., Desoeuvre, A., Casiot, C., Morin, G., Bertin, P.N., and Bruneel, O. (2016) Spatial distribution of eukaryotic communities using high-throughput sequencing along a pollution gradient in the arsenic-rich Creek sediments of Carnoulès Mine, France. Microb Ecol 72: 608-620.

Wallace, J.B., Eggert, S.L., Meyer, J.L., and Webster, J.R. (1999) Effects of resource limitation on a detrital-based ecosystem. Ecol Monogr 69: 409-442.

Witters, H.E. (1986) Acute acid exposure of rainbow trout, Salmo gairdneri Richardson: effects of aluminium and calcium on ion balance and haematology. Aquat Toxicol 8: 197-210.

Xiao, C., Chi, R., and Fang, Y. (2013) Effects of Acidiphilium cryptum on biosolubilization of rock phosphate in the presence of Acidithiobacillus ferrooxidans. Trans Nonferrous Met Soc Chin 23: 2153-2159.

Zhang, H., Yohe, T., Huang, L., Entwistle, S., Wu, P., Yang, Z., et al. (2018) dbCAN2: a meta server for automated carbohydrate-active enzyme annotation. Nucleic Acids Res 46: W95-W101.

Zirnstein, I., Arnold, T., Krawczyk-Bärsch, E., Jenk, U., Bernhard, G., and Röske, I. (2012) Eukaryotic life in biofilms formed in a uranium mine. Microbiology 1: 83-94.

Zou, K., Thébault, E., Lacroix, G., and Barot, S. (2016) Interactions between the green and brown food web determine ecosystem functioning. Funct Ecol 30: 1454-1465.

\section{Supporting Information}

Additional Supporting Information may be found in the online version of this article at the publisher's web-site:

Appendix S1: Experimental procedures.

Table S1. Number of reads per sample.

Table S2. Metatranscriptome assembly statistics.

Table S3. List of CaZy and Interpro entries that were predicted in metatranscriptome ORFs to define functional groups.

Table S4: Number annotated CDSs by sampling station.

Fig. S1 Expression values in transcripts by million (TPM) for functional groups of genes by order in each sample created with the rioja 0.8-5 package in $\mathrm{R}$ 3.6.3 ( $\mathrm{R}$ Core Team, 2020). The colour of squares indicate the sampling station (green $=$ Ams, blue $=$ Conf, brown $=$ Gal) and their size is proportional to the $\log _{10}$ of the corresponding expression value in TPM. The CaZy GH numbers and Interpro entries used to define the functional groups are given in Supporting Information Table S3.

Fig. S2 Average proportion of reads classified by Kaiju in the bacterivorous protist taxa Ciliophora, Amoebozoa, Choanoflagellida and Kinetoplastida. 